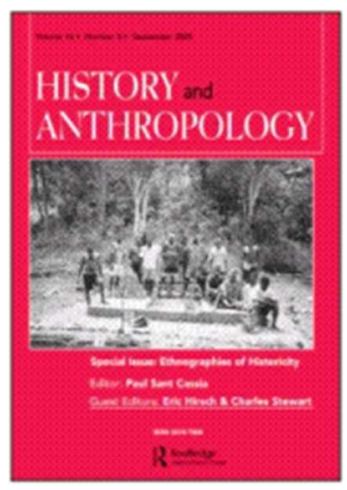

\title{
"Dying Out": Conversion and the Complexity of Neighbourliness on the Polish Belarussian Border
}

\begin{tabular}{|r|l|}
\hline Journal: & History and Anthropology \\
\hline Manuscript ID & GHAN-2016-0016.R3 \\
\hline Manuscript Type: & Original \\
\hline Keywords: & Poland, Borders, Christianity, Conversion, Neighbourliness \\
\hline \multicolumn{2}{|l}{} \\
\hline
\end{tabular}

\section{SCHOLARONE}

Manuscripts 
Main Text:

\section{Introduction}

During our first meeting, on the morning after All Saints Day, Bazyl insisted upon taking me on a walking tour of Kodeń's burial grounds. Initially he suggested that it was an opportunity for me to see first-hand the large number of cemeteries the small town had. Koden has four burial sites; the new Roman Catholic cemetery, the ecclesiastical graveyard at the rotunda and the shared Eastern Orthodox and Roman Catholic cemetery. As we walked through the shared cemetery, Bazyl stopped at a fresh looking grave, with the sandy soil of the Bug delta and an excess of plastic flowers still heaped on top of it. "Look," he directed me crouching down to the makeshift headstone. From the beginning of our walk, I had the impression that Bazyl's tour had a second motivation, that he saw the walk as an opportunity to point out the precarious state of the Eastern Orthodox Christian community in the area. Gesturing for me to look closer at the grave he told me, "here is another convert to Catholicism". Bazyl was able to tell because on the headstone, there was an "Orthodox name", yet the body was buried beneath the sign of the Roman Catholic cross. Until this first visit to the dead I had been surprised by how well the two main religious communities in Kodeń interacted and integrated. I was told constantly that this was the result of the simple practice of neighbourliness, a way of relating to difference that celebrated it, while minimising its disruptive potential. However, as I walked with Bazyl, I began to see that in Koden conversion challenged the practice of neighbourliness, laying bare the difficulty of negotiating the contradiction between valuing and minimising difference. It also became clear that conversion was not an event but a process that began at marriage and was only finally completed in the graveyard. In this way, even dead religious converts have a role in producing a sense of belonging, and the potential to disrupt such practices of relatedness.

Bazyl and I moved to the Eastern Orthodox side of the shared cemetery and he stopped, "here again" he said, pointing at an isolated Roman Catholic grave seemingly trapped on the wrong side of the imaginary line that divided the Roman Catholic and Eastern Orthodox dead. "This one is the child of a convert," Bazyl continued. He showed me the last name, how it ended in -iuk, an Eastern Orthodox name ending he assured me, but how the first name Piotr, was a Roman Catholic name. Later on other residents of Koden pointed out that -iuk is a Belarusian or Ukrainian name ending, demonstrating the entanglement of ideas of religion and ethnicity in the area. Bazyl, however, avoided mentioning this connection. Bazyl was using this walk to make his case that the ill fortunes of the local Eastern Orthodox community were directly related to the number of people 
who convert to Roman Catholicism for marriage. He told me there were many more Eastern Orthodox Christians in the town than was officially recognised. "Why else", he asked me, "are there flowers on the Orthodox graves?" The first of November is a Roman Catholic holiday, whereas the Eastern Orthodox remember their dead according to the Julian calendar and mostly during Easter- both by edict and local practice. Bazyl insisted that the number of flowers adorning Orthodox graves proved that many of the Roman Catholic locals had Eastern Orthodox kin to remember on All Saints Day, he also implied that he still regarded these converts as members of his religious community. I asked him why people converted, if it was true that the Church would not let them marry out of their faiths if they did not? Bazyl agreed that this was "apparently" the reason, but he did not really believe it. Instead, he said, "it is easier to be a Catholic here now. Ever since the end of the partition, it has been easier to be a Catholic. Germans and Austrians are Catholic but no one ever says, 'oh you're Catholic so you must be German, or Austrian' when you say you are Catholic. But if I say I am Orthodox, they say 'ohhh you're Russian"!' I am not Russian! My roots," he stamped his foot forcefully on the ground, "my roots, my grandfather, great-grandfather, ancestors, my son, they stood on this ground, they worked in Koden'". He was practically shouting by this point, when he paused. “Why not say 'oh you're Greek?' The Greeks are Orthodox! It is easier to be a Catholic here".

I begin with this moment as it was when I first realised how disruptive conversion could be, and what was at stake in the practice. The dead are involved in projects of relatedness, belonging, history making, and kinship. The responsibility to care for the dead is part of what allows people to maintain kin based relationships across generations. The converts buried in the town's cemeteries disrupt and confuse this responsibility. In trying to negotiate this confusion, unintended slights are perpetuated and offense taken. Placing flowers on an Eastern Orthodox grave in November may be an attempt to maintain the bonds of kinship after the fact of conversion, yet to the Eastern Orthodox minority it is one more act of attempted assimilation.

\section{A Town in the Borderlands}

I conducted my fieldwork in the religiously pluralistic town of Koden in $2011 / 2012$. The town is well known in the east of Poland as a Roman Catholic pilgrimage destination. Koden is in the province of Lublin, in south-eastern Poland, an area renowned for its natural beauty. The landscape consists of undulating cornfields, dense forests, and teeming swamplands edging the Bug River. Throughout the summer, people from all over Poland cycle along Bug River Trail, bringing much needed money to the area. The province of Lublin is bordered by Belarus and Ukraine to the east. 
There is an increasingly successful attempt to sell the area as an exotic holiday destination by Lublin's tourist board:

"The third largest Voivodship in Poland lies along the eastern borderlands of the country. Its neighbours are Belarus and the Ukraine across the wild and twisting River Bug. This is the region where Polish and Russian, Catholic, Orthodox and Jewish influences are all thoroughly mixed together. It is also a land that has seen many changes, a full-blooded borderland. ${ }^{\text {iii” }}$

Koden is located on the border with Belarus, which coincides with the river in this section. The association between the town and the border is important for local people, although they do not articulate it in the same way as the tourist board, as I will discuss later. During my fieldwork, there were approximately 3800 people scattered throughout the municipality, although only around 1800 resided in the town. Over half of the population were older than sixty-five or younger than eighteen years of age. At the time of my fieldwork, nearly seven hundred people were registered as unemployed, yet Kodeń was one of the economically better-off towns in the area. The new EU border regime, begun with Poland's accession to the EU in 2004, restricts trade and travel to Ukraine and Belarus. In doing so, it places severe limits on the wealth that eastern Poles once generated through economic activities with these countries (Zarycki 2011, 5). Despite media representations and academic studies approaching the 2004 accession as almost entirely positive (Komornicki \& Miszczuk 2010 cited in Zarycki 2011, 6), eastern Poland demonstrates the damage that hardening external EU borders can do. Transport links have diminished, and trade with Ukraine and Belarus has dried up (Zarycki 2011). While there has been an influx of EU funds, Galar points out that these are short term, periodic, and for use in specific projects; thus they fail to make up for the economic shortfall the closing of the borders entailed (2008 Cited Zarycki 2011, 7).

Kodeń's economic hardships were slightly alleviated by tourism and pilgrimage to the town. The town revolved around its Churches ${ }^{\text {iv }}$, particularly the large white Roman Catholic Basilica that dominated the town square. Evening mass was a place for older women to meet and gossip about the goings on in the town during the week, and on Sunday's families in their best clothes gathered outside after the services to discuss local and national news. The Basilica housed a holy image of the Virgin Mary, which attracted pilgrims to the area all throughout spring and summer. Through autumn and winter, Kodeń was very quiet, people struggled for money, so the arrival of the pilgrims and cyclists in early spring, and the money they brought with them, was a welcome event. In springtime local women opened up their homes as B\&B's, shops stocked up on tourist essentials, and a number of local people offered their services as guides or helped with activities like off- 
roading and kayaking. Large numbers of tourists converged on the town, drawn by the beautiful cycle trails and the Lublin tourist board's promise of a "full blooded borderland".

When I began my fieldwork, the residents of Koden were quick to inform me that the town was not really part of the Kresy. The Kresy - which translates as borderland - they told me, referred more directly to the south-eastern border with Ukraine. The local disavowal of the term Kresy clearly related to the fact it is a term normally indicating Polish border areas ripe with ethnic and religious tension (Buzalka 2008; Hann 1996; 1998; Hann \& Magocsi 2005). Pogranicze, literally on the border but normally translated as borderland (Buchowski 2004, 9; Czyżewski 2001; 2008) was the preferred term for the region. Borderland, as Buchowski clarifies, goes beyond the role the border plays in daily life, and includes the "long-term phenomena characteristic for such zones, as for instance bilingualism, intermingling, or interpenetration of cultures..." $(2004,9)$. The selection of one word over another to describe their place was part of a local strategy that clarified that this borderland was not an area of conflict. As mentioned above, Kodeń was religiously and ethnically diverse, although as I will discuss later, ethnic diversity was entangled with religious affiliation. Kodeń had a Roman Catholic majority, a large Eastern Orthodox Christian minority, and small numbers of Ukrainian Greek Catholics, Jehovah's Witnesses, and members of different Protestant congregations. Residents prided themselves on being borderlanders in the romantic tradition. That is, people shaped by the frontier; wild, anarchic, individualistic, creative and impulsive characters. I was frequently told that Kodeń, was a place where you could speak Ukrainian or Polish, go visit your family in Belarus, worship in an Orthodox, Roman Catholic or Ukrainian Greek Catholic church, but in the end, you all shared something, you were all from the Polish borderland. This emphasis on commonality was the heart of neighbourliness.

Despite its location on the Polish Belarusian border and the diversity of religious affiliations in the town, people in Koden constantly pointed out the conviviality between residents. This conviviality was commonly expressed through the concept of dobrosqsiedztwo, an apparently nonstandard local word meaning good neighbourliness or neighbourliness interchangeably. Neighbourliness can be explained as a set of practices, obligations and habits that recognised, minimised and organised difference. The homes of the area are generally one story tall, detached, and surrounded by small plots of land on which vegetables are grown. Doors remain unlocked, allowing neighbours to come and go as they please, and a large portion of the day was spent gathered around each other's kitchen tables. One's neighbours were primarily defined as the people likely to gather around your kitchen table, it was not proximity but practices that created a shared local life, which in turn formed neighbourly ties. This meant that when someone spoke of their 
neighbour, there was no indication of spatial distance, they may mean someone next door or at the other end of town. There was an indication of relational distance, however, your neighbours were "like family" without being kin, they were friends in whose everyday lives and personal histories you were entangled. Like kin, the neighbourly relationship survived across generations. Even in situations where historical upheaval had caused ruptures, current neighbourliness acknowledged division, while attempting to surmount it. Unlike the gossip around the basilica, neighbourliness had no connection to religious affiliation. The kitchen table, the centre of neighbourly relations, was a place where difference was minimised, and instead the shared experience of life in a small border town was emphasised. Nevertheless, in the cemeteries neighbourly behaviour could be disrupted. Instead of accepting and tolerating difference, the graves of converts were public documents of a practice that involved the assimilation and obliteration of difference in favour of the town's Roman Catholic majority.

The kitchen table was also the locus of small-scale economics. There was a lot of informal exchange and trade in the town, including goods from across the border. These goods were received at, and distributed from, a number of local kitchens. The town also had a number of small businesses selling food, farm supplies and second hand clothes; and one restaurant which opened irregularly, and which the older residents treated with suspicion. The bright green New Eastern Orthodox Church was the hearth of the local Eastern Orthodox minority, but drew mixed religious crowds on festival days. Non-religious events brought the whole town out to celebrate at the House of Culture. Despite the fact that there was no train station—small mini-buses were the only public transport available for travelling beyond the municipality - the town's residents had connections as far away as Warsaw and Chicago, challenging the idea that it was an isolated rural backwater.

However, the practice of neighbourliness, which I will detail later, was not straightforward. Neighbourliness relied on recognising difference and the same time minimising its impact. Interfaith marriage, and the resulting religious conversations, was a practice that endangered neighbourly ties, especially for the Eastern Orthodox minority. During my year of fieldwork in Kodeń, conversion was exclusively from Eastern Orthodoxy to Roman Catholicism. Historically, as we will see in the next section, conversion had often gone the other direction. The practice of converting from one Christian faith to another is linked to the historical dominance and suppression of different congregations in this area. However, since the end of World War II, the practice of conversion from Roman Catholicism to Eastern Orthodoxy has almost completely disappeared. The only conversions that I heard of or encountered directly were Eastern Orthodox to Roman Catholic, and all were occasioned by the decision to marry outside of the Eastern Orthodox faith. Conversions were highly 
potent moments in the local imagination, entangled as they were with relatedness, local knowledge, history, religion, death and, importantly, the ideal of respect for difference. They were moments that alluded to a difficult history and pre-empted the disruptions that eventually materialised in the graveyards of the town. In day-to-day life, local people rarely mentioned religious affiliation and seemed to socialise regardless of it, yet at the point of marriage - the moment of embracing someone as part of your network of kin - conversion was insisted upon. You can be a neighbour without sharing a religion, but becoming kin necessitated conversion. In this way, conversion complicated the local insistence that tolerance of difference was at the heart of the borderlander's attitude to life, and obliquely referred to a history where this was not the case.

\section{Family Histories of Conversion and Rupture}

Sometime in Spring, Hela, an old woman I had met at the Roman Catholic Basilica in the town, found out that I had been speaking to people about religious conversion. As we were leaving mass one evening, she told me that her family had a lively history of conversion and offered to talk to me about it, "if it would be helpful". So a few days later, over black tea and Belarusian cakes so sweet they made your teeth ache, Hela and I sat down to talk about her ancestors. Hela's family history was indeed eventful, it encompassed Roman Catholic, Eastern Orthodox and Greek Catholic conversions, and indirectly referenced a number of moments of turmoil within the town's history. She began by telling me we could disregard her father's side of the family altogether, "they have always been Catholic", she said abruptly. It was her maternal side that had changed drastically in the last four centuries. Her mother's side encompassed Eastern Orthodox, Roman Catholic and Ukrainian Greek Catholic ${ }^{v}$ families. One of her great-great-great Grandfathers had been a prominent member of the Greek Catholic congregation in Kostomłoty, the town next to Kodeń, tasked with keeping the keys to the Church and sanctum. After the establishment of the Kingdom of Congress Poland in 1815, Koden and Kostomłoty fell under the influence of Russia (Wandycz 1975, 74). At this time, there was an extensive Greek Catholic population in the East of Poland. At the 1596 Union of Brest, the Archbishop of Chełm brought the diocese of Kostomłoty into the Uniate Church, later called Greek Catholic (Keleher 1995, 365). In this Union, the Church of Kiev (an Eastern Orthodox Church) entered into communion with the Church in Rome. The subsequent Greek Catholic Church initially retained the Byzantine rite and the look and liturgy of the Eastern Orthodox Church, while acknowledging the Pope as their head (ibid). Throughout the commonwealth period directly preceding the partition, the Greek Catholic Church had become more Catholic in its appearance, while retaining its Orthodox liturgy. During the Kingdom of Congress Poland period, the initial multilingual aspect of the Church also began to change; in 1596 early forms of Ukrainian, Belarusian, and 
Polish were spoken and used by the clergy, while by the mid 1800's Ukrainian had become the defacto language of the Greek Catholic Church (Keleher 1995 366; 371). Although throughout this period the Church itself was losing parishioners to increasing Russian repression. The Tsarist regime encouraged Greek Catholics to "re-join" the Eastern Orthodox Church and initially, after the partition, pursued a policy of voluntary and coerced conversion to the Eastern Orthodox faith in Chełm, Ukraine and Belarus (Keleher 1995, 365). When this tactic did not yield results, they allowed much more violent campaigns: buildings were confiscated and practitioners executed.

The foundation of the Second Republic of Poland in 1918 offered a brief respite for Polish Greek Catholics, and Kostomłoty along with 40 other parishes returned to the Union of Brest (Keleher 1995, 368). However, after World War II, the Greek Catholic Parish of Kostomłoty once again found itself in lands controlled by Russia. The new Soviet Russian state forcibly closed a number of the revived Greek Catholic churches across Poland, Belarus and Ukraine. Kostomłoty survived the repression, it seems, by staying quiet and constantly implying they would join the Roman Catholics or Eastern Orthodox Church just as soon as the old parish priest died (Keleher 1995, 369). Keleher has a telling footnote in his 1995 article about Kostomłoty. He recalls visiting the parish and being asked to speak in Russian; this was despite the fact the locals spoke Ukrainian and Polish. He offered to speak in Ukrainian and was discouraged, as it might raise the "ethnic question" (ibid, 370). Hela told me that while her great-great-great grandfather had once had the bravery to stand up to a band of Cossacks and refuse to hand over the Church's keys, he eventually realised that life would be easier if he converted, and so that branch of the family became Eastern Orthodox Christians. Another branch of her mother's family had been Roman Catholic, but around the time of her great-great Grandmother had converted to Eastern Orthodoxy, which she assumes was due to the fact that at the time Kodeń's Basilica had been converted to an Eastern Orthodox Church, implying that Eastern Orthodoxy was the accepted religion in the area. Hence, for the next three generations her mother's family remained Eastern Orthodox Christians.

Hela's mother met her father during the brief interwar period in which the Polish State was re-established with new borders, meaning that Kodeń was located more centrally than before. Her parents married before the outbreak of World War II, after her mother converted from Eastern Orthodoxy, and as part of this conversion agreed to raise her children in the Roman Catholic faith. The marriage caused consternation on both sides of the family. Her father's family could not understand why he would marry an Eastern Orthodox woman when there were so many "amicable and beautiful catholic girls ${ }^{\text {vi” }}$ in the town. Meanwhile, Hela's mother initially suffered near constant reprimands from her family over her agreement to raise her children Roman Catholic. Hela was born 
during the war, after the German-Soviet demarcation line had again adjusted Poland's boundaries, placing Koden directly on the eastern border under the influence of Russia. Hela was brought up Roman Catholic, but recalls her mother often telling her "though I married your father, a Catholic, remember the Catholics and the Orthodox celebrate the same Christmas and even Easter, even though the Orthodox celebrate a week or two later, you have to celebrate Catholic and Orthodox". Hela told me that her mother often took her "quietly" to Eastern Orthodox festivities, but all that stopped in 1947.

When the Nazis subjugated the East of Poland in 1941, they issued papers to the population that identified their "ethnicity" alongside their other details. Many of the area's Eastern Orthodox and small Greek Catholic population found themselves with papers marked with a small $u$, which identified them as Ukrainian. This identification was haphazard, often based on religious affiliation, local hearsay, or convoluted notions of "blood inheritance" (Snyder 2003, 198). Near the end of World War II, the Ukrainian Insurgence Army (UPA) began bloody activities in the south-eastern Polish borderlands (Hryciuk 2002, 101-117; Piotrowski 1998, 242-258). To resolve the Polish/Ukrainian land disputes and curtail the actions of Ukrainian nationalists, the Soviet state believed it was necessary to create ethnic uniformity in each country, defined according to the Molotov-Ribbentrop Pact borders delineated in 1939 (Snyder 2003, 220). This began with transnational repatriations from 1944 to 1946 , moving about 780,000 Poles and Jews out of Ukraine. In 1947, the UPA assassinated the Polish Defence Minister, leading to renewed calls for the control or expulsion of the Ukrainians residing in Poland (Piotrowski 1998, 244-45). On the day following the assassination, it was decided, that "As soon as possible, an Operational Group should be organized, to form a plan for the complete extermination of the remnants of the Ukrainian population in the south eastern border region of Poland among other things" (Snyder 1999, 109). This meant "resettl[ing] Ukrainians and mixed families in the regained territories, without forming any tight clusters and no closer than 100 kilometres to the border" (Snyder 1999, 108). The resettlement plan was called Akcja Wisła, Operation Vistula, after the river that divides Poland in half (Snyder 2003, 197). Operation Vistula began in 1947. It focused on three provinces Rzeszów, Lublin, and Cracow. Over the course of four months approximately 150,000 people (30,000 families) were relocated (Kersten 1991, 392). A further 3,936 men and women were sent to a concentration camp in Jaworzno, as they were believed to have ties with the UPA (Snyder 2003, 200). During the operation, soldiers would surround a village and a senior officer would enter and read out a list of those to be resettled; the selected families would then be given a few hours to pack twenty-five kilograms of luggage. After this, the villagers would be marched to a halfway stop where they would later board cattle freight trains ${ }^{\text {vii }}$ to the Recovered Territories in the west (Misiło 2013, 222-225). It is important 
to note that the ethnicity of those relocated was generally determined by the presence or absence of a $u$ on their Nazi-issued papers (Snyder 2003, 198). After Akcja Wisła, Hela's mother did not talk so much about celebrating together for a long time. Many of the family Hela remembers from before her $10^{\text {th }}$ birthday were gone.

Koden was part of the Lublin province at the northern corner and as such subject to Akcja Wisła (Czeberkus 2007, 7: Kuprianowicz 2007, 12; Matreńczyk 2007: Snyder 1999, 113). However, Akcja Wisła was not the only state action against the Eastern Orthodox Christians in this area in the years surrounding World War II. In 1938 the Polish state instigated a policy of "Polonization" as part of Akcji Polonizacyjno-Rewindykacyjnej na Chełszczyźnie i Południowym Podlasiu, Operation Polonization-Restitution of the Chełm and Southern Podlasie Regions in Lublin Province. The operation followed a speech by the governor of Lublin in 1935, in which he declared that "regaining independence the Orthodox Church has been a factor of russification and in recent years begins to play the role of a factor in ukrainization." (APL, UWL WSP, 430. translation my own) He argued the state could not afford to put off the polonization of the Bug River area, hoping the local people would learn to be true Polish citizens. He declared it was time for "polonizacji prawosławia" the polonization of the Orthodox (ibid). Primarily the aim was to convert Eastern Orthodox Christians to Roman Catholicism, and thus avoid them falling under the influence of Ukrainian or Russian agents. The action aimed to do this by convincing people that their ancestors had actually converted from Roman Catholicism under duress from the Tsar. They were to convince Eastern Orthodox families that a return to the Roman Catholic faith was necessary and would improve their relations with neighbours and advance their material conditions. Alongside this, "inactive" Eastern Orthodox churches were to be closed down or changed to Roman Catholic churches (Mich 1994, 101). However the operation led to the burning of a number of Eastern Orthodox churches along the Bug river viii and according to Papierzyńska-Turek the demolition successfully diminished the Eastern Orthodox faith in the area, weakening its influence and significantly affecting the number of Eastern Orthodox families in the area $(1989,373)$.

Yet Hela did not discuss the 1938 polonization operation, instead she firmly laid the blame for the diminished Eastern Orthodox population on Akcja Wisła. It took many years for the Eastern Orthodox population on the eastern borderlands to recover from Akcja Wisła, those that were not relocated often chose to leave villages they no longer felt welcome in (Snyder, 1999). Families that had escaped relocation came back slowly in the 1950's and many of the others returned after a few decades in West Poland. 
Somehow, the town's diverse religions managed to get along, despite the sometimes-violent history of ascendancy, repression, conversion and expulsion in the years prior. Partially this was done through the concerted practice of neighbourliness: Through recognising differences, but insisting they are not as important as the shared borderland belonging. This is perhaps apparent in how Hela chose to begin and end her tale. When I first turned on my recorder, she put down her tea and leaning into the machine she began, "Yes, so when it comes to me, to my family. Oh in my family we were everything, everything!" At the end of her story, which she enumerated with almost no interruptions from me she folded her hands across the table and said "so, oh, for me it's no matter whether you are, for example, Jewish or a Jehovah's Witness, come in and I will offer you tea, thank you. I have my Catholic faith, but yes..." Hela's family history was not unusual, except perhaps that she narrated it so clearly, an indicator of rehearsal and retelling. The form her story took echoes the form of the Myth of the Kresy. The emphasis is on the loss of a mythic past, where borderlanders lived together without the need for conversion or conflict (Zarycki 2013, 209). Yet, even the town's founding family converted from Eastern Orthodoxy to Roman Catholicism, at the height of the period covered by the Kresy myth (the 1600's) when the political moment made it expedient. This act initiated a continuing debate over the provenance of the red brick Chapel, the first church built in the town by the Eastern Orthodox founder of the line Iwan Sapieha, and subsequently the claim that the town is primarily Roman Catholic. Many of the towns Eastern Orthodox residents argue that it is Iwan and not his great grandson Mikołaj who shaped the town, and thus that the town is really an "Orthodox town" not a Roman Catholic one. What Hela's story demonstrates clearly is the contradictory lives and afterlives of the town's converts, both new and old. While she was remonstrated by her family for her conversion, Hela's mother sought to remain active in both religious communities. Even as she raised her children as Roman Catholics, she insisted that they value the similarity between their two faiths and encouraged them to celebrate in both. While maintaining a strong Roman Catholic faith, Hela professed a respect and tolerance for religious diversity. Yet, the history that informs the religious choices of her ancestors belies this egalitarian approach to neighbourliness.

\section{Neighbours, Borderlanders, and Converts}

\section{Neighbours and Borderlanders}

Pasieka writing about the south-eastern Polish border (2015) spends a lot of time trying to untangle the practice and discourse of neighbourliness. At the heart of the process, she finds a contradiction between blurred and bright boundaries (citing Alba 2005). Blurred boundaries are 
moments when differences are minimised, and bright boundaries are the instances when difference is accentuated. In the practice of neighbourliness, boundaries are simultaneously blurred and bright. Pasieka discusses the local practice of refraining from work when neighbours celebrate religious holidays, regardless of affiliation. She states that "the common recognition of neighbours' rituals accounts for blurred boundaries, while respecting different festivities simultaneously underlines the brightness of boundaries" (Pasieka 2015, 153). In discussing neighbourliness with the residents of Kodeń, however, I primarily encountered the idea of the borderland and borderlander. For the people I spoke with, the borderland was a place that gathers many different identities and ideas, it was a place for difference. Krzysztof Czyżewski, a borderland poet, puts this more lyrically when he says "In the borderlands, a man lives in the shadow of the Other. He lives because he struggles with him, engages in polemic with him, profits from him (even if it is only in the form of theft)" $(2002,20)$. This encounter with the other has also concerned anthropologists working in borderlands. Green has argued that the marginality experienced by residents of the Greek/Albanian border is a complex interplay of ambiguity and ordinariness, captured in the idea of being "just Greek" $(2005,82)$. "Just" can mean that you are simply one thing or that you are barely that thing, the precise meaning only becoming clear in the negotiations of daily life in the borderlands (Green 2005). This is perhaps why Wolf and Cole insisted upon analysing the process of the border in the "imponderability of daily life" of a small Italian Alpine village $(1974,24)$. Managing the ambiguity of the borderlands position in wider understandings of the nation is part of the work of everyday life, and in Koden the residents have found that neighbourliness allows them to do this.

Neighbourliness underlies most of the sociality of Koden; economic choices are guided by it, religiously diverse friendships rely on it, celebrating together and giving gifts are all said to express it. In Koden barter, cross border trading and gifting were all essential parts of the local economy and all relied on neighbourly ties (Joyce 2015, 81). Most of the locals kept chickens and small vegetable gardens, but only a small number of people had larger livestock. Subsistence farming was an essential part of the local diet, and barter was an important part of this. The family that kept cows sent the milk to a number of neighbours who turned it into cheese, returning some to the family and keeping some themselves. Often they further exchanged this cheese, passing it onto neighbours who would produce pierogi, again keeping some and returning the rest. This form of exchange relied on the knowledge people had of their neighbours skill, and on trust that they would not be taken advantage of. Younger people would often help the elderly residents of the town in the garden and with small household repairs. My own landlady, an older Eastern Orthodox woman, spent Wednesdays and Fridays visiting housebound Roman Catholic and Eastern Orthodox neighbours. As Henig observed in Bosnia, neighbourliness is a social process that required face-to-face sociality and 
moral practices $(2012,5-6)$. Your neighbours were not just those who lived close to you, but also those who lived with you (ibid, 15). In Kodeń, the religious differences between neighbours added another element of difficulty to the process of neighbourliness, and the emphasis on the borderland identity aimed to elide this. Neighbourliness that takes the borderland as its starting point must, at all costs, avoid resolving the contradictions of the border. It must acknowledge that the local area is constructed in the interaction between self and other. In this way, by celebrating the practice of neighbourliness, the residents of Koden ensure that they remain respectful and positive about the diversity of their home place.

\section{Converts}

In other writings about Poland, there is debate about the extent to which mixed marriage and conversion maintain the contradiction at the heart of neighbourliness. Pasieka observes that unlike most cases, mixed marriage in Poland does not involve a final choice; people remain active in both communities even after conversion. She believes that this demonstrates that mixed marriage does not disrupt but is guided by ideas about neighbourhood $(2015,154)$ ). Babiński (working on the Polish-Ukrainian and Polish-Czech borders) on the other hand, sees mixed marriage as the perfect tool of assimilation, noting that converting to Roman Catholicism to marry equates to becoming a Polish national for his respondents (ibid, 154). I sit somewhere between these two opinions. Conversion is a process that begins at marriage - when the converts name is entered into the Roman Catholic parish's marriage records - and ends with death and burial. The converts name is not removed from the Eastern Orthodox Church's records, but they are like a cut branch, all future children and grandchildren appear in the Roman Catholic parish's list of births and marriages, the convert's death is marked in the Roman Catholic - and not the Eastern Orthodox - records.

Throughout this process, converts try to negotiate their places within two communities, avoiding the trap of assimilation. Conversion is an in-between space where religious practice is adjusted in an attempt to maintain the careful valuing and minimising of difference. However, at the moment of death the convert is finally and irrevocably assimilated into the faith of the majority.

Joel Robbins suggests that conversion creates "divided subjects", people constantly working to leave the past behind and live according to the "event" of conversion $(2010,641 ; 647)$. However, this approach is built on an understanding of the moment of conversion as a moment of Pauline radical unexpected change (ibid, 633). That is, change that comes as the result of an unexpected event, not from social circumstances reflecting the role of religious affiliation in the historical process. Robbins' model of conversion does not fit the context of the conversions I discuss here, nor 
does it reflect accurately the practice of the converts. Unlike Robbins' divided subjects, Koden's converts do not struggle to move beyond their in-between position; instead, they embrace it until the moment of their death. However, like Robbins' converts, they are aware of the contradiction of their new lives. Unlike classic definitions of conversion that focus on the personal transformation, the form of conversion I am discussing in this paper is deeply social. As Pelkmans' has demonstrated in the post-soviet case, we cannot understand conversion without analysing "what made conversion a conceivable option" $(2009,5)$. Conversion is a personal act that reflects social conditions and has far reaching social consequences (ibid, 6). In the case of Kodeń's converts, it connects to a long history of religious discord and compulsory conversion. The choice the Eastern Orthodox converts make is understood socially through the lens of the recent historical oppression of the community. The 'polonization' campaigns of 1938 and the relocations of 1947 decimated the local Eastern Orthodox Christian community. Since the end of socialism the numbers have been slowly growing, but this growth relies on increasing the number of young people in the community, and mixed marriages seem to threaten this.

Perhaps this is why conversion was particularly spoken of as "dying out" by the Eastern Orthodox population of the town. Throughout their lives, converts live in the shadow of eventual full transformation at the moment of death. They also live in the shadow of the region's history, particularly the persecution of the Eastern Orthodox in the $20^{\text {th }}$ Century. Having survived this, the Church now faces the possibility of losing members to voluntary conversion. Dying is the act that finally removes the convert from the day-to-day rituals of the Eastern Orthodox Church, but it is only one in a number of steps in the process of conversion. I want to return to this final stage of conversion in the next section. For now, I want to focus on the initial part of the process of sublimating religious difference, marriage.

The practice of converting for marriage stems from a local interpretation of Roman Catholic doctrine regarding mixed marriagesix. Originally, Roman Catholic Canonical Law forbid "marriage between two baptised persons of whom one is a Catholic; whereas the other is a member of a heretical or schismatic sect" (1917 Code of Canon Law). As late as 1970, Pope Paul VI was discouraging marriage outside of Roman Catholicism. The Pope believed mixed marriages caused family problems and risked the Roman Catholic partner's obedience to the Church (Apostolic Letter, Matrimonia Mixta 1970). Despite this, the influence of Vatican II's liberalisation led to changes in the 1983 Code of Canon Law. A mixed marriage was still invalid, unless the couple marrying received special dispensation from the diocese (canon 1124, 1983). Dispensation was, however, normally granted so long as the couple were married according to Canonical form. This means a ceremony 
performed by a priest and attested to by at least two witnesses, with the effect of necessitating that the marriage take place in a Roman Catholic church. Canon 1127 seems to allow a couple to marry in an Eastern Orthodox church (as Eastern Orthodox Christians are seen as schismatic but not heretical). In this case, the marriage is valid but it is also illicit, without dispensation from the Roman Catholic Church. According to Eastern Orthodox canonical tradition, marriage must be performed in the Eastern Orthodox church, and the partner must convert, anything less leaves the parishioner in bad standing with the Church. In Koden, the priest had the final say on whether a couple could apply for special dispensations to marry. The Eastern Orthodox Church's hard line, and the complexity of the Roman Catholic Church's law, led to a situation where (in all cases I heard of) the couple decided to marry in the Roman Catholic basilica. The local belief that in order to marry in a church one must convert, led to the situation whereby Orthodox locals converted to marry Roman Catholic partners. It is also worth noting that Canon Law on both sides of the marriage is not in favour of interfaith marriage; reading through the texts, there are references to ignorance and schismatics, and undeniably hostile language, which would perhaps encourage one to convert anyhow.

The Eastern Orthodox Church's tradition is much the same as the Roman Catholic Church's law. Yet for some reason, it is almost unheard of for an interfaith marriage to take place in the Eastern Orthodox Church in the town, or in the surrounding towns. Most people were of the opinion that you "must" convert to marry a Roman Catholic, and perhaps the complicated Canon Law and negative attitude to interfaith marriages give this impression. When I asked about the phenomena, the local priests were fuzzy on the reasoning for pre-marriage conversion, but they were clear that it was a necessity and that it had always been so. The three local Roman Catholic priests I spoke with all suggested that it was far better for couples to practice the same faith when raising children together. This is a particularly clever answer as, worldwide, receiving a dispensation for mixed marriage involves the Roman Catholic Church official receiving a promise that children will be raised in the faith. In other words, official Church rules clarify that the children of mixed marriages must be raised Catholic, and local priests can ensure conversion by emphasising the importance of parents and children sharing the same faith. In this way, local priests can insist on conversion without invoking regulations, instead emphasis the pastoral care rational.

In May I attended the wedding of my landlady's grandniece. The bride's father (my landlady's nephew) had converted to Roman Catholicism to marry her mother. The wedding was held in the basilica, yet attended by Roman Catholic and Eastern Orthodox locals and family. While certain bodily engagements marked the religious division of the attendees — differing styles of making the sign of the cross, and confusions around when you should sit, stand and kneel-, what I 
found most remarkable was the number of occasions when both faiths were in union: in the hymns, the liturgy, and in some bodily practices, such as standing for the Gospel. I also noted how, on both sides, the congregation was altering its practices to fit better with those of their neighbours: singing in Polish, standing for prolonged periods of time, and so on. After the wedding, the guests retired to the local House of Culture for food, drink and dancing, until the wee hours of the morning. I left early with my landlady to help her set up bedrooms for the guests from out of town. She was silent as we unfolded beds and tidied away furniture. Eventually I asked, a little self-consciously, if she was okay. She sighed, and sat down shaking her head. "Now Wera (the bride) is gone, when she was little her father would bring her to the Orthodox Church, but then she grew up and stopped going. Now who will bring her children, her father? No he won't." She sighed again and slowly got to her feet, "only old people now are Orthodox, we are dying out, Aimee"

\section{Kinship and a Ukrainian-Orthodox Identity}

"Everyone is worried because the Orthodox in this area are dying out. They marry Catholics and then their children are raised Catholic, every year there are fewer and fewer Orthodox children baptised." (Paulina interview: Kodeń, 06/2012)

Family and religion are intimately linked in the laments of Koden's Eastern Orthodox community. Complaints about conversion or dying-out always related to concerns about the continuation of kinship groups and wider networks of relatedness. Young people increasingly understood that Eastern Orthodoxy and Belarusian or Ukrainian ethnicity were entangled, while the organised Church emphasises the Ukrainian connection. The Eastern Orthodox Church increasingly mediated learning Ukrainian", celebrating "Slavic" holidays, and learning traditional songs etc. In this way conversion was no longer purely a religious act, it was also an act that ultimately destroyed the "natural" bonds of family, based on ethnic origin. Theologically, continuance is vital to the Eastern Orthodox faith. The Church maintains that it is the true Christian Church, sustaining an unbroken line from the days of Christ to today, liturgically and in its practice. It is worth noting that local Eastern Orthodox Christians often reminded me that the Polish word for their faith prawosławny could also be translated as two words, prawo - sławić, meaning to glorify correctly. In this way any break with the faith is a rupture with a whole history of continued correct worship, regardless of whether the convert remains active in the Church or not.

This interweaving of the social and biological in understandings of "natural kinship bonds" reflects Janet Carsten's work on relatedness. In her 2000 book on relatedness, Carsten begins with an account of the changes that the study of kinship underwent in the preceding decades of 
anthropological debate. Echoing Schneider, she demonstrates a shift to studying the process of kinning, rethinking blood ties as primarily an articulation of social relatedness, clarifying that there was always an element of choice in biological connectedness. Carsten goes on to examine how "culturally specific domains" such as religion and kinship, "have been dialectically formed and transformed in relation to each other" $(2000,15)$. Thinking of relatedness as an ongoing process means thinking of the practices that maintain and build relationships, the small everyday acts across a diverse range of domains that construct an idea of a "natural" kin group. In this section then, I want to focus on the dialectic relationship between religion and relatedness, particularly the impact the narrative of conversion is having on practices of kinship, specifically in relation to children.

In the 1980's there was a slow increase in the number of Eastern Orthodox Christian organisations in Poland. This included the establishment of many new Youth Organisations and the Archdiocese of Lublin-Chełm. This development had a great impact on the social lives of the youngest Eastern Orthodox generation in Koden- those born in the 1990's and later. There were a few seminaries or Eastern Orthodox social clubs active in the area during and directly following socialism, a result of the diminishing population of Eastern Orthodox Poles caused by the polonization and relocation operations. Roman Catholic, Eastern Orthodox, and Greek Catholic populations were educated together. It was not until the 1980's that the middle generation had the option to socialise exclusively with Eastern Orthodox Christians, and this was normally small-scale or during one-off occasions such as religious festivals. Now, an increasing number of Eastern Orthodox Youth Organisations, choral groups, and pilgrimage associations occupy the spare time of the youngest generation. While their grandparents seem able to socialise regardless of religious affiliation, and their parents attempt to socialise exclusively with other Eastern Orthodox Christians only at specific events, the youngest generation is the first in this region to socialise predominately with other Eastern Orthodox Christians.

Members of the youngest generation meet other Eastern Orthodox Christians during their leisure activities. I interviewed three young people who stopped over in Koden during a pilgrimage to the Eastern Orthodox monastery of Jabłeczna. I was amazed at the number of activities they undertook with a mono-religious group. All three were members of their local Church choir; one also acted as an altar boy frequently. All three were members of a youth organisation that held an annual weeklong camping event in Grabarka ${ }^{\mathrm{xi}}$ every summer, as well as frequent meet-ups on feast days throughout eastern Poland. They all took part in a number of walking pilgrimages during the summer, these type of events are a common way for Polish young people of all faiths to spend their summers. On these pilgrimages, they were usually part of young people's groups set up by the Church but 
advertised through Facebook. This intensive socialising, coupled with the small numbers of Eastern Orthodox young people, lead to an acutely connected and familiar generation.

Parents encouraged this type of socialising, and this left many young people feeling like their parents had ulterior motives. There was only a small number of Eastern Orthodox young people in Koden but I managed to speak with most, and one thing that came up repeatedly in our conversations was a sense of pressure from parents to find Eastern Orthodox partners. Parents seemed equally anxious about their children and the wider Eastern Orthodox community. When I spoke to parents about mixed marriages, they were clear that it was bad for the community, but more specifically that it put the partner who converted under a great amount of stress trying to keep both sides of their new family happy. Yet, parents own preference for children marrying within the faith generated its own stress. One local young man told me he had attended Białystok University specifically to improve his chance of meeting and marrying an Eastern Orthodox girl. Another told me that although he was never told directly to find an Eastern Orthodox wife, the negative feelings about mixed marriages expressed by his parents left him in no doubt as to their preferences. However, neither young men were too upset by their parent's interventions, both were active members of Eastern Orthodox youth groups and desired to remain active in their religious community.

While conversion does not mean that families stop talking, it interferes with the motherchild bond so culturally celebrated in Poland, in both the Roman Catholic faith and the iconography of the Eastern Orthodox faith. Agnieszka Kościańska, writing about conversions to new age religion in the urban centres of Poland, discusses the same fear that the alteration of family roles will ultimately lead to the destruction of family ties $(2008,175)$. When the Brahma Kumaris convert's obligations to feed, nurture, and love are turned outward to a global community, it risks their role as mothers, as they are no longer focused on the needs of the nuclear family. The bonds of kinship, in this case intimately attached to providing a certain type of care and to the continuance of this form of social attachment, are broken. While conversion in the case of Koden does not require any remarkable changes to behaviour, it does require that children are raised according to the principles of Roman Catholic faith. Mothers, particularly the mothers who convert, are placed in the middle of demands from both sides of the family that they cannot possibly fulfil. For an Eastern Orthodox grandmother raising a child right, involves the usual childrearing skills, and includes the need to raise the child to be aware of their heritage. This need is further complicated because in Koden religion and ethnicity overlap in many different ways. Most of my Eastern Orthodox respondents were insistent that Eastern Orthodoxy did not equate to Ukrainian heritage, emphasising instead their 
extended families in Belarus. However, the local Eastern Orthodox Church used Ukrainian prayer books, and invites to the biggest non-religious Eastern Orthodox festival, Malanka, were written in Ukrainian and Polish. Toward the end of my fieldwork, the Eastern Orthodox diocese of LublinChełm began preparing for a month of Akcja Wisła remembrance events, including a conference and an essay-writing competition for under-eighteens. The motivation for the event, I was told by a representative of Archbishop Abel, was to commemorate the suppression of the Eastern Orthodox faith in the period after World War II, and to encourage Eastern Orthodox children to learn more about their heritage. The increasing incorporation of Ukraine history into the Church's calendar of events demonstrates growing concern with ethnic genealogy in the religious realm. In this way the failure to raise your children in the Eastern Orthodox faith, not only separates them religiously from their kin, it also, as I was told, occasionally risks erases their ethnic identity.

\section{Eastern Orthodox Lives after Conversion}

I want to turn now to how converts live after marriage. In doing this I wish to adjust slightly Pasieka's understanding of the interaction between neighbourliness and mixed marriages. Unlike Pasieka, I do not believe that the neighbourly practices which guide the lives of converts ultimately prevent them from becoming blended into the culture of the majority $(2015,154)$. However, I wish to demonstrate that while conversion is a process that eventually ends in the erosion and assimilation of difference, throughout this process the convert strategically uses the ideal of neighbourliness to maintain membership in two religious communities.

There was an aspect of interfaith marriages that my respondents rarely discussed: even after the marriage and the supposed choice of one faith above the other, families continued to be part of both communities. At the Eastern Orthodox feast of St Nicholas in Zabłocie Janek, an elderly man, pointed out to me a woman and child blessing themselves in the Roman Catholic style. "Mixed marriage", he grumbled. "Well, she is still bringing the children to the church", I offered. "They are Catholic though", he retorted. I do not have time to delve into the inner religious lives of converts in this article, nor is that the focus of this piece. However, I do wish to note that throughout my fieldwork, religion was imminent and often unexamined in the lives of the town's people. Religious belief was most clearly articulated in relation to extraordinary religious events or religious difference. Nevertheless, even in these moments, most people explained, they became aware of their inability to articulate their own sense of the divine. Instead, the everyday world of religion - an undefined mass of mundane activities that contain extraordinary and ordinary moments in dialectic balance is most often apparent in practices that relate to religious objects and traditions (Ammerman 2007; 
Schielke \& Debevec 2012). Festivals, home decorations, education, Sunday mass; these are the moments when Eastern Orthodox converts attempt to negotiate their old and new lives. The choice to attend an Eastern Orthodox festival, but to venerate the icons there in a Roman Catholic style, demonstrates the attempt to balance alliances, but it confuses the theology of both faiths and means that the action is incorrect in the eyes of both congregations. In trying to keep both sides happy, the convert accidently ensures that neither are. This was not the only time I saw this kind of double religious life. Many of the interfaith families were active in both communities, regardless of which they officially belonged to.

Malanka is a semi-religious event held at the start of January; a Russian, Ukrainian, and Belarussian folk holiday held on Old New Year, or the Eastern Orthodox date of New Year's Eve, normally around January $13^{\text {th }}$. Every year, for the past thirty years, the local Eastern Orthodox population has gathered in Biała Podlaska for dinner and dancing to celebrate New Year and the Eastern Orthodox Community itself. From the moment of my arrival in Kodeń in late October, my Eastern Orthodox respondents were excitedly discussing Malanka. Bazyl and Paulina were two of the main organisers, and every time I was out with either, they would stop frequently to ask if people had bought tickets yet, or to discuss the food and music planned for the event. In fact, Bazyl would also use these occasions to build a tally of local converts for my benefit. For example, after shouting across the street to a middle age woman, asking how many tickets she wanted, he turned to me and sadly shook his head, "she's a convert, her husband won't come, only the children." Bazyl refused to be impressed, as I was, that this woman would still bring along her children. He told me the children would not really understand the holiday if they have not been taught about it in a Church group. I objected that I had also only just learnt of Malanka, but he pretended not to hear me. In the end, approximately 200 people attended the event. When the party finally wrapped up at quarter to three in the morning, Bazyl gave a slightly teary-eyed speech, during which - in among a seemingly endless list of thank you's - he took a moment to reflect, that even though the community was shrinking, this was the largest turnout the event had ever had.

Although converts may try to live in both communities, by doing this, they ensure they fit properly into neither. The Roman Catholic Priests often told me that the Eastern Orthodox converts failed to embrace their new faiths fully. And indeed, many converts simply did not attend mass nor make any effort to get involved with wider Roman Catholic activities like choir, cleaning the church, giving tours of the Basilica or attending meetings called by the Parish priest. Instead, they continued to attend Eastern Orthodox festivals and to keep Eastern Orthodox style images in their homes. In the end, however, the final decision about their place in the two communities was not theirs to 
make. Upon death, the convert was fully assimilated into the Roman Catholic Church and buried in a Roman Catholic grave.

\section{Conclusion}

I found it hard to find evidence for or against the general Eastern Orthodox opinion that they were dying out. At the festival in Zabłocie, nine children had received their first communion and yet Janek remained cantankerous throughout. He later told me that these children had come from all over the Lublin-Chełm diocese. "Look around Kodeń" he demanded "and tell me how many Orthodox families there are now. Then count how many Orthodox people have Catholic families". It proved difficult to do as he asked, and even more difficult to find any previous surveys of the Eastern Orthodox population. The local priest told me he had approximately 50 regular church attendees, but he estimated about 150 parishioners in the area, about $5 \%$ of the local population. Festivals around Koden could attract up to 200 people, but it was difficult to tell if all of them were active in the church. According to the 1931 census, the Eastern Orthodox made up 11.8\% of the population. The 2011 census counts them at $0.7 \%$ of the overall population (Polish Statistical Year Book).

According to Bazyl's informal tally, there were approximately 12 recent converts in the town, and who knows how many in the surrounding area. Yet, I always saw the people he pointed out to me at festivals, and sometimes even at mass. When I spoke to Marek, the caretaker at the local cemetery about his conversion he was quick to point out he had not abandoned anything. He listed off the events he had attended recently and told me that his eldest daughter still went to Eastern Orthodox festivals, even though she lived away from him. In fact, Marek did not really think of himself as a convert, it was a practical solution to the problems posed by a mixed marriage. I asked him what he thought of the local fear of dying out, but he could not really answer. Eventually, he said that he agreed with it, but that it might not happen for a few generations. However, he wondered if his great grandchildren would know anything about who he was before he converted, would they know he went to all the festivals even after he converted? These questions demonstrate how death realises the threat of assimilation that conversion carries. Once Marek is no longer around to live between two churches and to tell his own story, his double life will eventually fade from his family's memory. He will be remembered as a convert, but what that actually entailed will be forgotten. The borderland ideal, which acts always to minimise conflict, here eventually acts to simplify the practice of conversion.

Many Roman Catholics in Koden were the product of multiple interfaith marriages. What was striking about these people was how easily they articulated their complex family histories and 
how frequently many insisted there was no real need to divide the faiths. Hela was one of these, she told me, as she saw it, religion's main purpose was moral guidance: "they teach you not to be an animal". Even those who could trace their heritage back as seamlessly Roman Catholic frequently spoke in the same way of religious difference, emphasising its presence while minimising the effects of this presence. One woman told me: "We are all Christians and the Orthodox are very close to us, they have the same belief in the Blessed Mother Mary," adding pointedly "the Protestants do not."

However, the challenges faced by the Eastern Orthodox residents of Kodeń, did not allow for this easy-going ecumenicalism. For my Eastern Orthodox respondents, their experience of daily religion was shaped by how deeply they internalised the "normality" Of Roman Catholicism in Poland (Pasieka 2013). If in Poland to be normal is to be Roman Catholic, then the Eastern Orthodox Christians have to explain and justify their "unusual" religious practices and beliefs. More so, as Pasieka points out, the way that history is recounted, taught, and disseminated produces an almost unchallenged connection between the Polish nation and Roman Catholic religion, leaving nonRoman Catholics as de-facto "others" (Pasieka 2013). Religious affiliation is tied to the Eastern Orthodox sense of exclusion from cultural intimacy in Poland. If, as Herzfeld contends, cultural intimacy is a "recognition of those aspects of a cultural identity that are considered a source of external embarrassment but that nevertheless provide insiders with their assurance of common sociality", then "the familiarity with the bases of power ... may at one moment assure the disenfranchised a degree of creative irreverence and at the next moment reinforce the effectiveness of intimidation" $(1997,3)$. Although the degree to which Roman Catholicism is a source of "external embarrassment" can be debated, it is a vital part of the sense of cultural intimacy apparent in the category of the "Polish Catholic". The question that conversion asks is how far the concept of neighbourliness can stretch and how much it can protect the Eastern Orthodox residents of Kodeń from assimilation.

Despite the fact that it is the act of an individual in the present, conversion cuts across past and present, collective memory and personal histories, community and individual. Most importantly, conversion threatens historical forms of belonging in the borderlands; the headstones of the converts that Bazyl and I visited, and with which I opened this paper, do not necessarily speak to a complex history of interfaith marriages and compromises, only the final moment of rupture the process of conversion began. The principal of neighbourliness and the networks of relatedness in the town also respond to conversion. On the one hand, Eastern Orthodoxy - and Roman Catholicism provides a sense of belonging to a particular family, and these bonds are difficult to break. At the same time, when someone converts, they negotiate a new way of belonging within a new family 
nucleus. As in all acts, this negotiation is framed by the borderland ideal, finding a way to acknowledge and yet diminish the impact of difference. The success of this attempted give and take depends on the response of the wider communities and the alternative social expectations of different generations and community members.

Framing all of these compromises are the long-term relations between two religious communities, with entangled histories of inequality, displacement and dispossession. While members of both communities make use of modes of coexistence based on the ideal of the borderland, they also hold on dearly to their differences, as this is what provides them with a strong sense of historicity. Converts, however, inhabit an in-between space where their presence and their actions, aimed at maintaining their connection to Eastern Orthodoxy, instead seem to upset those who want to revive and strengthen Eastern Orthodoxy and the community in the area. However, these same actions forestall the moment of rupture and assimilation as converts do not just abandon their Eastern Orthodox past; instead, they negotiate it as part of their new Roman Catholic life-world until the moment of their death.

\section{Bibliography}

Alba, R. 2005. "Bright vs. Blurred Boundaries: Second generation assimilation and exclusion in France, Germany and the Unites States." Ethnic and Racial Studies 28(1): 20-49

Ammerman, N., ed. 2007. Everyday religion: Observing modern religious lives. Oxford: Oxford University Press.

Archiwum Państwowe w Lublinie (APL), Urząd Wojewódzki Lubelski (UWL); Wydział SpołeznoPolityczny (WSP), [State Archive in Lublin, Provincial Office of Lublin, Social and Political Section] Reference number 430.

Buchowski, M. 2004. "Granica a uprawianie antropologii - uwagi wstĊpne" [Border and practicing anthropology - introductory remarks"], In, Polska-Niemcy. Pogranicze kulturowe i etniczne / PolandGermany. Cultural and Ethnic Border. Edited by Buchowski, M. \& A Brencz. Wroclaw: Polskie Towarzstwo Ludoznawcze.

Buzalka, J. 2008. Nation and Religion: the Politics of Commemoration in South-East Poland. Münster: LIT Verlag, . 
Carsten, J. 2000. "Introduction". In Cultures of Relatedness; new approaches to the study of kinship. Edited by J Carsten. Cambridge: Cambridge University Press.

Code of Canon Law: Pio-Benedictian. 1917. Translated by Peters, E.N. San Francisco: Ignatius Press.

Code of Canon Law: Latin-English. 1983. Washington: Canon Law Society of America.

Cole, J. W. and E. R. Wolf. 1999. The Hidden Frontier: ecology and ethnicity in an alpine valley. Berkeley: University of California Press.

Czeberkus, P. 2007. "Z Dziejów Kodeńskich Cerkiew...[From the history of Kodeń’s church]” Istocznik 3: 6-7

Czyżewski, K. 2001. Ścieżka pogranicza / The Path of the Borderland. Sejny; Pogranicze.

Czyżewski, K. 2002. "The Path of the Borderland" Irish Pages 1(1): 12-24

Czyżewski, K. 2008. Linia Powrotu: Pogranicze [The Line of Return: Borderland]. Sejny; Pogranicze.

Davies, N. 1979. Gods Playground: A History of Poland; the Origins-1795. Oxford: Clarendon.

Green, S. 2005. Notes from the Balkans; locating marginality and ambiguity on the Greek Albanian Border. New York: Princeton University Press.

Hann, C. 1996. "Ethnic Cleansing in Eastern Europe; Poles and Ukrainians beside the Curzon Line". Nations and Nationalism: 2(3):389-406.

Hann, C. 1998. "Postsocialist Nationalism; Rediscovering the Past in Southeast Poland". Slavic Review 57(4): 840-63.

Hann, C., and P.R. Magocsi, eds. 2005. Galicia: a multicultural land. Toronto: University of Toronto Press.

Henig, D. 2012. "'Knocking on my Neighbours Door': on metamorphoses of sociality in rural Bosnia". Critique of Anthropology, 32(1): 3-19.

Herzfeld, M. 1997. Cultural Intimacy; social poetics in the nation state. London: Routledge. 
Hryciuk, G. 2002. “Akcje UPA przeciwko Polakom po ponownym zajęciu Wołynia i Galicji Wschodniej przez Armię Czerwoną w 1944 roku [Actions of the UPA against the Poles after the re-occupation of Volyn and Eastern Galicia by the Red Army in 1944]" (pp: 101-117). In Antypolska akcja OUN-UPA 1943-1944: fakty i interpretacje [Anti-Polish action of OUN-UPA 1943-1944: facts and interpretations]. Vol. 4. Edited by Motyka, G. Warsaw: Inst. Pamięci Narodowej .

Joyce, A. 2015. "Good Neighbours and Bad Fences: everyday Polish trading activities on the EU border with Belarus". In Ethnographies of Grey Zones in Eastern Europe. Edited by I. Harboe Knudsen \& M. Demant Frederiksen. London, Anthem Press.

Keleher, S. 1995. "Trapped Between Two Churches: Orthodox and Greek-Catholics in Poland" Religion, State and Society, 23(4): 365-371

Kersten, K. 1991. The Establishment of Communist Rule in Poland, 1943-1948. Translated by Micgiel, J. \& M.H. Bernhard. Berkeley: University of California Press.

Kościańska, A. 2008. "On Celibate Marriages: Conversion to the Brahma Kumaris in Poland." In On the Margins of Religion. Edited by Pine \& de Pina-Cabral New York: Berghahn Books.

Kuprianowicz, G. 2007. “Akcja 'Wisła' i Jej Skutki dla Kościoła Prawosławnego [Operation Wistula and it's effects on the Orthodox Church]" Elpis 9(15/16): 11-38.

Matreńczyk, A. 2007. "Przeszłości nie Udało się Zatreć [The Past unsuccessfully wiped out]”. Przegląd Prawosławny. 6 (264).

Mich, W. 1994. Obcy w Polskin Domu: nacjonalistyczne koncepcje rozwiqzania problemu mniejszości naradowych 1918-1939 [Strangers in the Polish House: nationalist ideas to solve the problem of national minorities 1918-1939]. Lublin: Wydawnictwo Uniwersytetu Marii Curie-Skłodowskiej.

Misiło, E. 2013. Akcja Wisła 1947. Dokumenty i Materiały [Operation Wistula 1947. Documents and Materials]. Warsaw: Archiwum Ukraińskie.

Papierzyńska-Turek, M. 1989. Między Tradycjq a Rzeczywistościq: Państwo Wobec Prawosławia 1918-1939 [Between Tradition and Reality: State views of the Orthodox Church 1918-1939]. Warsaw: PWN.

Pasieka, A. 2013. "Being Normal in Poland" Transit Online: 1-7. 
Pasieka, A. 2015. Hierarchy and Pluralism; living religious difference in Catholic Poland. New York: Palgrave Macmillan.

Paul VI. 1970. Matrimonia Mixta [Apostolic Letter in the form of Motu Proprio on Mixed Marriages]. Accessed Last, August 8, 2016.

Pelkmans, M. 2009. "Introduction: Post-Soviet Space and the Unexpected Turns of Religious Life". In Conversion After Socialism: Disruptions, Modernisms and Technologies of Faith in the Former Soviet Union. Edited by Pelkmans, M. Oxford: Berghahn.

Piotrowski, T. 1998. Poland's Holocaust: Ethnic Strife, Collaboration with Occupying Forces and Genocide in the Second Republic, 1918-1947 London: McFarland \& Company.

Polish Statistical Yearbook 2012 available at http://old.stat.gov.pl/gus/5840 2844 ENG HTML.htmRobbins, J. 2010. “Anthropology, Pentecostalism and the New Paul: conversion, event and social transformation" South Atlantic Quarterly. 109 (4): 633-652.

Schielke, J S, and L. Debevec, eds. 2012. Ordinary lives and grand schemes: an anthropology of everyday religion. Vol. 18. New York: Berghahn.

Snyder, T. 2012. "“To Resolve the Ukrainian Problem Once and for All": The Ethnic Cleansing of Ukrainians in Poland, 1943-1947." Journal of Cold War Studies 1(2): 86-120.

Snyder, T. 2003. The Reconstruction of Nations. New Haven: Yale University Press.

Wandycz, P. S. 1975. The lands of partitioned Poland, 1795-1918. Washington: University of Washington Press.

Weltzer, H. 2008. "Collateral Damage of History Education: National Socialism and the Holocaust in German Family Memory" Social Research. 75(1): 287-314

Wylegała, A. 2015. "Child migrants and deportees from Poland and Ukraine after the Second World War: experience and memory." European Review of History: 22(2): 292-309.

Zarycki, T. 2011. "Eastern Poland in a centre-periphery perspective." In Strategic issues of the development of the Lublin region. Lublin: University of Economy and Innovation. 
Zarycki, T. 2013. "Debating Soviet Imperialism in Contemporary Poland: On the Polish uses of the Post-Colonial Theory and Their Contexts" In Empire De/Centred New Spatial Histories of Russia and the Soviet Union. Edited by S. Turoma, M. Waldstein Kupovykh. Surrey: Ashgate Publishing..

\footnotetext{
'Throughout this article, when quoting directly from what people told me I will follow the local Polish practice of referring to Eastern Orthodox Christianity as Orthodoxy (Prawosławny), Roman Catholics as Catholic (Katolikami) and Greek Catholics as Uniate (Unicka). Otherwise I will use the formal names

i' Basyl used the word 'rosyjski' here not the somewhat offensive 'ruski' which was often used when speaking about history and informal trade in the town.

iii From http://www.poland.travel/en/regions/the-lubelskie-voivodship-the-bug-river-trail (last accessed 24 February 2016).

iv In Polish, there are two different words for church, kościół and cerkiew. Kościół is used to indicate a Roman Catholic church, and cerkiew is used to indicate an Eastern Orthodox church.

${ }^{v}$ There is some complexity in the use of names for the Ukrainian Greek Catholic Church. Historically, Uniate, Neo-uniate, Greek Catholic, Ukrainian Greek Catholic, Byzantine Rite Catholic and Eastern Rite Catholic have all been used in this area. I will use Greek Catholic as it is the most recognised term in Poland, outside of Uniate, which has negative connotations beyond Poland.

${ }^{v i}$ From interview with Hela

vii According to Anna Wylegała (2015) "cattle freight wagons" are a topos of memory (citing Weltzer 2009) which comes to symbolise the suffering of displaced Poles, more so than a reflection on the actual mode of transport.

viii A complete list is kept by the Polish Eastern Orthodox Church and can be accessed here, http://www.cerkiew1938.pl/index.html

${ }^{\mathrm{ix}}$ In this case, mixed marriage refers to marriage between two baptised people where one is a member of one Christian faith and the other is a member of a different Christian faith. Marriage outside of Christianity has a different set of rules for both Roman Catholics and Eastern Orthodox Christians ${ }^{x}$ In this part of Poland it would make more sense to learn Belarussian, given that most families have family living in Belarus, but Ukrainian classes are offered by the church.

${ }^{x i}$ Grabarka is a mountain in the north east of Poland. It is the most important religious site for the Eastern Orthodox Christians in Poland. In August, to celebrate the feast of transfiguration there is a mass pilgrimage to the mountain.
} 